\title{
Representation of Business Culture in Selected Malaysian Short Stories
}

\author{
Zanirah Wahab (Corresponding author) \\ Centre of English Language Studies, Faculty of Languages and Communication, Universiti Sultan Zainal Abidin, Gong Badak Campus, Malaysia \\ E-mail: zanirah@unisza.edu.my \\ Radzuwan Ab Rashid \\ Centre of English Language Studies, Faculty of Languages and Communication, Universiti Sultan Zainal Abidin, Gong Badak Campus, Malaysia \\ E-mail: radzuwanrashid@unisza.edu.my
}

Received: 29-05-2016

Published: 01-11-2016
Accepted: 06-08-2016

doi:10.7575/aiac.ijalel.v.5n.6p. 147
Advance Access Published: September 2016

URL: http://dx.doi.org/10.7575/aiac.ijalel.v.5n.6p.147

\begin{abstract}
Globalisation has brought numerous changes in all aspects of life especially in the economic sector. For the past few decades, the importance of economic growth and achievement has become the "obsession" of people around the world. Malaysia is no exception to this economic globalisation whirlwind. As well-known business hub with cutting edge technologies and blooming business enterprises, economic globalisation has shifted the way Malaysian society view things or connect with one another. This paper explores how business culture is represented in Malaysian short stories as well as examines the stand of the writers regarding the impact of economic globalisation on their society. In doing so, this paper compares and critically analyses three - selected short stories in the light of globalisation theory. The five main characteristics of globalisation namely, internationalisation, liberalisation, universalisation, westernisation and deterritorialisation are taken into account while dissecting these literary works. From the analysis, each writer voices out similar concerns regarding the impact of economic globalisation on their society. Malaysian fictions are preoccupied with the erosion of good values and the nation's physical changes due to economic globalisation. The parallel stand demonstrates that regardless of their ethnicity and gender, they react uniformly to the changes.
\end{abstract}

Keywords: Globalisation, economy, Malaysia, fiction, business culture; short stories

\section{Introduction}

The advent of the new millennium has seen the progress of globalisation soundly progressing and affecting all countries around the globe in all aspects of life, from politics to culture. For the past few decades, the importance of economic growth and achievement has become the "obsession" of people around the world, from the First to the Third World countries (Hirst, Grahame, \& Bromley, 2009). The standard bar is set higher and higher as time goes by and with positive economic development comes great changes especially in technology which shifts the way people see things or connect with one another. The present economic milieu has been adequately summarized by a British sociologist, Herbert Spencer who defines the fierce nature of free market economies as "a twist of social Darwinism [...] in which the 'fittest' would naturally rise to the top" (Steger, 2003, p.40). The same applies to humanity where this never-ending competitive environment has said to change the values in society to that of selfishness and materialism.

There is no exception in Southeast Asia which is full of economic potentials. Among these countries, Malaysia appears to be one of the most competitive countries (based on The Global Competitiveness Report 2014/2015 published by World Economic Forum and the 2014 World Competitiveness ranking by the IMD). Malaysia is ranked number 20 out of 144 economies in terms of global competitiveness and number 6 in the Asia-Pacific region. Currently, Malaysia is striving to achieve the status of a developed country by the year 2020 as publicly announced in its Vision 2020 policy (Yussof, 2009). Even though its economic growth may not be as smooth or brisk as its neighbouring country, Singapore, Malaysia has progressed considerably from being an agriculture-based economy into an emerging multi-sector economy (Ali, 2010). Its potential is also being recognized by the world based on the favourable rankings aforementioned. With a population of approximately 29.90 million in 2014, and various natural resources such as petroleum and palm oil, it is not impossible for Malaysia to follow its neighbour's footsteps in becoming the next developed country within the next decade.

With such a remarkable history of economic growth, it is natural to ponder upon the impact of these economic achievements on its citizens in facing such drastic economic changes. The questions of how citizen feel about these rapid developments brought by economic prosperity and their reactions towards these phenomena has proven to be another engaging and necessary study. One of the best ways to study these responses is through literature as one of the many functions of literature is to reflect the current happenings in society. Hence, this study aims to examine the impact 
of these economic achievements onto the psyche of Malaysian citizens and their reactions in adjusting to such rapid development given that business culture has been given greater emphasis in this present society. It also aims to investigate how the citizens feel about these rapid developments brought by economic globalization and their reactions towards these phenomena. The stand of these authors in the matter is also of interest, whether they react uniformly to the changes, or differently according to their respective ethnicity and gender.

\section{Methodology}

Three short stories have been purposely chosen from three anthologies of short stories published in the first decade of the $21^{\text {st }}$ century. The short stories are namely, "Mala" by K. S. Maniam, taken from The Merlion and the Hibiscus: Contemporary Short Stories from Singapore and Malaysia (2002), "Corporate Giant" by Muhd. Nasruddin Dasuki (Faridah Noor Mohd Noor, Trans.), taken from Anthology of Asean Literature: The Cosmopolitan Tradition (2000), and "A Tale of Two Cities" by Rachel Chan, taken from Urban Odysseys: KL Stories (2009). These stories are written by writers from different generations and represent the three main ethnic groups in Malaysia as to represent the multiethnic and multi-cultural setting in Malaysia. The short stories are selected based on their theme and the issues tackled in the narrative which deal with globalisation and how economic development has affected Malaysian society. Each narrative offers its audience invaluable insights on the effects of globalisation through its portrayal of everyday lives of ordinary people struggling to survive the challenges of the increasingly competitive world as these are penned through first-hand experiences. Similar to the methodological approached employed by Priyatni (2016), this study used content/contextual analysis of the texts as to provide a thorough examination of the subject-matter.

\section{Analysis}

Kuala Lumpur, being the heart of Malaysia, is the first place to be affected by the overwhelming economic growth especially after the government's rigorous efforts towards privatization as it was conceived as a solution to the expansion of public sectors and inefficiencies (H. Osman Rani, 2007, 15). By making this as the setting for "Mala", Maniam weaves a story about a simple woman who desires nothing but a domestic bliss. However, the marriage she dreams actually brought her far from her village to the fast developing city of Kuala Lumpur. In order to survive, she has to adapt very quickly to her new surrounding and role in her husband's new startup company. She is forced to "discard her saris and wear dresses" (Maniam, 1985, 80) and stop rubbing turmeric on her face. Her husband buys her lotion and makeup and asks their neighbor, Lucy to teach her how to use them. When Lucy is done with her, she gasps as "her face resembled that of the women she had seen at the shopping complexes" (80). At this point onwards, her process of assimilation into modern society has begun. In a blink of an eye, she finds out that modernisation has stripped her of the freedom she thought she has gained by leaving the village. She is now caught in her husband's dream of becoming financially successful, who manipulates her by using her own wish to lead a simple life against her. In her effort to fit in, she loses a part of her identity and control over her own life. She realizes that "she had changed ... but into someone not of her making" (Maniam, 1985, 82). She has been reduced to a mannequin by her husband and her current circumstances, of being new in the city and financially dependent on her husband, have robbed her of her voice.

While Mala symbolizes the Indians' struggle in the ever expanding Malaysia's economy, her husband, Sanker appears as the product of economic globalisation. The ideology of universalisation has seeped into the mindset of those who seek satisfaction through material things like him. He defines his future success as having "a better, new car, move out to a house in a prestigious area, fly to a holiday in a foreign country" (K. S. Maniam, 1985, 79) as these are symbols of success according to the English movies he so often watches. This idea, propagated again and again over time through the most powerful medium, the mass media, has become ingrained into everyone's mind, defining what success is and how it is the only purpose in life (Scholte, 2000). At least this is true for him as he believes it is the ultimate form of survival, either he sprints to the top or be eaten at the bottom of the food chain. The world is tough and ugly from his perspective. His determination to improve his life at the beginning of the story changes into a scary obsession where his hunger for material success drives him to bully his wife. He does this by forcing her to fit his idea of a perfect wife, a modern, sophisticated wife, and exploiting her naiveté to his advantage. She works without a salary because he reasoned that they are married and is forced to wait on any man who comes to his office. Over the time, his obsession has become a burden as whenever he talks about his business, he will become restless and sleepless.

However, not everything is bad. Sanker's determination can be seen as a portrayal of motivation and drive from the author to the readers as Sanker is very hardworking and industrious until even Lucy, who is of Chinese descendent, equates him "like Chinese himself" (Maniam, 1985, 77). Thus, Maniam, by portraying Sanker as representing the "new" Indians in a way wishes that more of his ethnic members to emulate the good traits from the Chinese who are known for their independence, diligence and business-minded, traits that everyone should possess if they want to enjoy what economic globalisation brings forth to this shore without stripping their identity.

Similar struggle and issue are also being voiced out in "Corporate Giant". The competitive world as depicted in the storyline of this narrative embodies a sense of power of the market and its endless capacity to manipulate and speculate which makes capitalism as part of the nature of business. At the end, these ideas have become the defining horizon of the contemporary experience of capitalism. The world according to its protagonist, Mazlan is "like the world of politics ... not impossible for friends to become enemies" (Dasuki, 2000, 111). Figuratively, the story projects the world of business as a battlefield where for the sake of survival, friends turn against each other as only the one who survives will rule. Mazlan acknowledges, "It's true that in the business world putting others out of business is what we do. Something that's constantly happening to our race" (Dasuki, 2000, 110). The last sentence of the excerpt is an observation from him after he has struggled for nearly a decade and even experiences betrayals from his own race when 
his so-called friend sabotages his project. Through the portrayal of Mazlan, the reality of the Malays is revealed where Dasuki delicately expresses his thought that it is a shameful situation as it shows the eradication of Malay values such as co-operation, give and take, mutual help and unity which are no longer upheld by the Malays themselves.

These changes are what anthropologists and sociologists call the Gesellscheft paradigm, a situation when urban dwellers possess those characteristics which come under Gesellscheft, such as being industrious and individualistic as opposed to the Malays' original state of Gemenscheft, which is more family and communal oriented (Selat, 2000, xiiixiv). The slow but certain transformation is definitely poisonous for the Malays as the nuances of disunity are becoming apparent. The fragile relationship between Mazlan and business competitor, Azman is just an allusion to this serious problem that Dasuki is trying to convey where if this is not treated at once, it will destroy the Malays from the inside (Mohamad, 2002). He also poses a bigger question of the possibility of retaining one's racial identity in the era of globalisation as seen through the characterisations of Mazlan and Azman. Although "Corporate Giant" exposes the unpleasant side of the business world, it compliments this negativity with Mazlan's character that, amidst all these has remained true to himself. He is pictured as a modest businessman even though he has earned a favourable reputation and recognition within the business circle and does not wallow in the praises thrown in his way. Here, the author displays that it is possible for one not to be affected by one's own success or be consumed by one's determination to succeed in the material world.

Unlike Mala, the strong character of Mazlan shows that it is possible for one to adapt without compromising his identity and principles. The author has chosen to represent Mazlan as a character who seizes the opportunity he gets but not at the expense of undermining his integrity. For him, this is the formula that Malays must understand and practice in their life as the nature of business is unpredictable. The setbacks in business are inevitable but one's business reputation will be remembered for a long time. The stereotypes that have long plagued the Malays must be totally debunked if they want to be perceived as worthy competitors in the corporate world. Even though the business world is being projected as a merciless and uncompromising world, the author is still optimistic when he reminds his readers that in spite of the seemingly heartless portrayal of this world, there are still true friends who are willing to lend their hand to help others who desperately need one. Mazlan is sincere when he offers to help Azman and even shares his observations with him regarding what is wrong with his company's management. However, Azman is insincere when he repeatedly overpraises Mazlan on his achievement in the story to a point that it seems like he resents his success. One of such instances is when Mazlan repeats his sincere wish to assist him despite his continuous mocking of Mazlan's success:

"I believe your words are not meant to be cynical. You're a Malay, I'm a Malay, it's not healthy to be suspicious in the business world. I want to help my own race!" Mr. Mazlan tried to convince his friend (Dasuki, $2000,110)$.

It is undeniable that "Corporate Giant" echoes economic globalisation and the intricacies of the business and management at its heart. As Mazlan is pictured as a role model in the business world with his flair for business, a calculative mind and creative management skills, Azman is on the other hand is not. His ruthlessness and dishonesty in the past, where he even sabotaged his childhood friend's business deal and tried to sell pirated products are actually destroying his reputation. He still distrusts Mazlan until the end and calls his effort to help as a "trick" (Dasuki, 2000, 109). This world has changed Azman from an innocent village boy to a paranoid and suspicious person. He is like a wounded, shell-shocked soldier from a business war where he only has two choices left, either to fight back or retreat and get help from Mazlan. Unfortunately, he chooses not to take up Mazlan's offer for assistance because of his stubbornness and ego and fails to see the implication of his action.

So there are still Malays who do not believe in their own race, sighed Mr. Mazlan while slapping his forehead. He could see his own people walking as if they were passing through a dimly lit alley." (Dasuki, 2000, 117)

"Corporate Giant" is full of social commentaries on Malays and their business ethics. Dasuki is very bold and vocal in assessing his Malay society as they need to overcome these shortcomings in order to favourably compete with other races in commerce and trade which have long been dominated by the latter. This is also a call for action by the author to his society because if they still do not change, the game will be superseded by others.

Interestingly, "A Tale of Two Cities" also chooses to represent business culture through the depiction of Kuala Lumpur from the eyes of her narrator who has seen its transformation from a muddy land to a ground full of megalith buildings and shopping malls. The life of the narrator is quite similar with this city where he comes from the outskirt of Kuala Lumpur. With his love and admiration for nature, it never occurred to this unnamed narrator that one day, he will become a successful developer who tears apart everything that he used to love. Starting his life as a person who does not give much thought to money, he quickly changes as rapidly as Kuala Lumpur when he discovers the unpleasant truth about the workings of the materialistic world when he learns that he is being married off to a distant cousin because she comes from a rich family. Because of his penniless state, he has no power to stop the marriage even though he has fallen in love with someone else. Feeling hurt and insulted with "the perfect business arrangement" (Chan, 2009, 44), he vows to prove to everyone that he can also be as financially successful as them, if not better.

Choosing to be involved in business, the narrator quickly rises to the top, starting as a supervisor and later becoming a manager at a construction company due to his knack for trade and a bit of luck. Soon, he is transformed into the very "city folk" he used to hate (45) and starts to be engrossed with his new life. The taste of success and money numbs him "like a dose of opium" (49) until he totally forgets the reason that has brought him there in the first place. Materialism successfully begins to reign his life when he starts to judge people based on the size of their wallet instead of who they 
are when he admits that:

[...] I must have forgotten why I was there in the first place - to show the rich that I could make it too-

because I had become one of them, and turned up my nose at the poor. (Chan, 2009, 46)

Tan draws a parallel between her narrator's changes with the changes to the city when she likens her narrator's life to a coconut tree which is described in the earlier part of the story as "strong and unyielding ... nobody's slave" (Chan, 2009, 43). The narrator used to declare, "... how I admired the strength of the trees as they fought against the wind, always resisting the forces of change" (43). Therefore, when he cuts down the trees and replaces them with a concrete jungle, he is in a way, stripping himself off his true identity for wealth. He has become a slave for money, wasting his life with more and more business meetings and golf courses, "entertaining small talk which meant nothing" (Chan, 2009, 52). However, unlike Mala, he is in control in his life (largely because of his gender) and amends his wrongdoings at the end of the narrative. The realisation dawns on him when the news of his daughter's illness acts as a wake-up call for him. He stops to reflect on what he has done and realizes that his daughter is sick because of his action, exchanging his principles for the sake of wealth which at the end, still fails to fill in the emptiness he feels ever since he got involved with business. Finally, he decides to take a bold action to free himself from this "materialist cycle" (Chan, 2009, 51). He learns the hard way that his quest for success, "hopping from one business opportunity to another, always searching for something, but gaining nothing in the end" (51), has made him overlook the most important thing that he has in life.

He soon realizes that the development that he has helped to bring, especially shopping malls, does not actually benefit everyone as only those who are rich can enjoy them while the rest who live in villages behind these shopping malls, the only thing they can enjoy is their "squalor-filled craters of developer-made wreckages laced with a blanket of mosquitoes" (Chan, 2009, 47). Even though they also live in the midst of "beautifully engraved plazas" in the city, their standard of living really contrasts with that of the well-to-do folk that frequent the malls. They struggle to make ends meet every day by scavenging the "leftover" from these developments. What is left for them are "pieces of broken brick and crushed cement (which) add to the vision of a destroyed civilisation" (Chan, 2009, 47) even though initially he justifies that these landmarks have created a lot of job opportunities for them.

These graphic imageries by the author are reflections of her stand of the impact of globalisation onto her society. From her perspective, this allusion to the economic disparity even among city dwellers is not to be taken lightly either by the government or the citizens. Tan further illustrates that economic prosperity seems to only profit those who bring about these transformations while the rest can only observe them from far. Her narrator fails to understand the impact of his action as he is among the beneficiaries when he declares that he has become "one of them" (Chan, 2009, 46). Thus, he does not care whether the development he ushers in is beneficial to his society or destructive. For him, this only serves as another mean or "the biggest stepping stones" to become materially successful (47).

Tan also paints a very strong imagery when she uses the phrase "destroyed civilization". The rapid economic transformation of Kuala Lumpur is equated to a typhoon, destroying everything in its path. The word "civilization" (sic) in this context has become ironic. Instead of referring to it as sophisticated urban society, the narrator feels that the real civilisation is actually the villages that the multi-storey buildings had replaced. During these old days, the narrator observes that the villagers are very close knitted. Everyone sincerely cared for one another which is in contrast to modern materialistic society where they exploit one another in order to maximise their profits and minimises costs. Thus, the former according to the narrator's perspective, is the real civilization. At this point, the author criticizes the modern globalisation which has eradicated the romantic values of the narrator's society. Tan also compares the current situation to the time of the Malacca Sultanate when economic globalisation first hit this shore (Zainal Abidin Abdul Wahid, 2008, 123). The narrator, while observing a colourful crowd at Masjid Jamek, suddenly finds himself imagining that he was transported to this era where:

[...] the maritime port, abuzz with silks and various languages. The Malay language would arise above all, the final call for the last bargain of cloth. People treated each other as friends; whether you came from the West or the Far East, they looked upon you as their kin. We were all here to mingle and trade. Not to exploit one another for our riches. Not a slave to anyone's mastery." (Chan, 2009, 50)

These traders from various parts of the world do not just bring to this land their goods, but also their languages and cultures. However, these differences do not pose any problems as everyone recognizes each other's differences. No one has to change in order to be accepted. Their sincere intention to earn a living has prevented them from being slaves to greed and wealth. When the narrator comes to this understanding, he starts to see that the most important thing that he needs is his family, not the hollow comfort of material wealth. With this comparison, Tan hopes to correct the widespread negative perception of the business world. It does not necessarily need to be ruthless, but instead, it is just a tool for everyone to make an honest living.

In these narratives, economic globalisation causes people to become more fixated on accumulating wealth and the nature of business itself has transformed from being just a war of survival to become the survival itself. Other than that, the over-competitive attitude makes people become more individualistic and self-centred until up to a point of being selfish. Traditional values widely practiced by Malaysians before like sincerely caring and helping each other, especially those in need are slowly being stamped out of their daily life. They have become suspicious of one another as a result of the lack of communication and understanding of one another because they are too busy working. Because of this, Rachel Tan through her narrator in "A Tale of Two Cities" believes that the old villages are in reality more civilized than the urban society in terms of their manners and compassion for humanity. All three authors believe that excessive desire 
for acquiring wealth is destructive, not only to an individual but also to their society in general. Another concern is regarding one's identity. A lot of characters in these selected stories undergo a behavioural transformation. They show the tendency of becoming monoculture where everyone adopts the same values such as competitiveness, and act towards the same goal, i.e. to achieve economic prosperity.

The impact of globalisation is also evident in all of these stories. The expansion of economy as a result of economic globalisation for instance is made clear by these authors through the symbolic shopping malls which have been emerging not only in Malaysia, but also on all continents, offering consumers who can afford the luxury, products from all parts of the world. Apart from their physical appearances (attire, etc.), the action and way of thinking of the protagonists is also the outcome of their daily contact with their globalised society. Their experiences of global interdependency for example, especially in terms of economy, have gradually changed each protagonist's identity as well as their respective society which thus have dramatically impact the way they react to globalisation in their globalised community.

\section{Conclusion}

Malaysia is a multicultural and multiracial society. Therefore, it is not unexpected to see the diversity of experiences of economic globalisation among their colourful citizens. From these short stories, it is clear that Malaysian authors have focused on similar issues. Malaysia is still in the process of establishing itself as a developed country. Hence, the impact of economic globalisation from the perspective of these authors in their narratives is unique to their particular societies. It is clear that the reactions of these Malaysian authors are the same when it comes to the effects of economic globalisation onto their society regardless of their gender and ethnicity. One of the effects of economic globalisation which is being repeatedly highlighted by them is the erosion of tradition and its good values which has given way to the so-called modernisation. This is the price society has to pay and these authors, through their narratives, are trying to remind their society that traditional values can co-exist with the fast pace world today. From their perspective, it is clear that Malaysian society is still adjusting to the swift arrival of economic globalisation where they still have many things to learn before they can achieve the status of a developed country.

\section{References}

Ali, S.H. (2010). The Malays: Their problems and future. Petaling Jaya: The Other Press.

Chan, R. (2009). A tale of two cities. In Janet, T. \& Eric, F. (eds.), Urban odysseys: KL stories (pp. 43-52). Kuala Lumpur: MPH Group Publishing.

Dasuki, M.N. (2000). Corporate giant. In Selat, N. \& Lynne, K. (eds.), Anthology of Asean literature: The cosmopolitan tradition (pp. 109-117). Kuala Lumpur: ASEAN committee on Culture and Information.

Hirst, P.Q., Thompson, G.F., \& Bromley, S. (2009). Globalization in Question (3rd ed.). Cambridge: Polity Press.

Mohamad, M. (2002). Globalisation and the new realities. Selangor: Pelanduk Publications.

Malaysia-Overall Performance. (n.d). Retrieved from https://www.worldcompetitiveness.com/OnLine/App/Index.htm>

Malaysia: The millennium development goals at 2010. (2011). Retrieved from http://www.undp.org.my/uploads/mdg1.pdf

Maniam, K. S. (2002). Mala. In Mukherjee,D., Singh, K. \& Quayum, M.A. (eds.), The merlion and the hibiscus: Contemporary short stories from Singapore and Malaysia (pp.67-86). New Delhi: Penguin Books India.

Mohamad, M. (2002). Globalisation and the new realities. Selangor: Pelanduk Publications.

Scholte, J. A. (2000). Globalization: A critical introduction. New York: Palgrave.

Selat, N. (2000). Preface. In Selat, N. \&, Lynne, K. (eds.), Anthology of Asean literature: The cosmopolitan tradition (pp.xi-xxiii). Kuala Lumpur: ASEAN committee on Culture and Information.

Steger, M. M. (2003). Globalization: A very short introduction. Oxford: Oxford University Press.

Rani, H.O. (2007). The encyclopedia of Malaysia: The economy (Vol. 13). Singapore: Archipelago Press.

Wahid, Z.A.A. (2008). Kerajaan Melaka dalam hubungan antarabangsa: Polemik sejarah Malaysia. Kuala Lumpur: Arkib Negara Malaysia.

Yussof, I. (2009). Malaysia's economy: Past, present and future. Kuala Lumpur: Malaysian Strategic Research Centre. 